MICHA J. CZARNECKI

Instytut Politologii UMK

\title{
Między tyranią a cezaryzmem. Komentarz do dyskusji Erica Voegelina z Leo Straussem
}

Wie narażając się na zarzut zbędnej przesady, można powiedzieć, iż klasyczna filozofia polityki zrodziła się „z” dyskusji oraz „w” dyskusji. U jej korzeni leży spór z sofistami, rzecznikami doxai, jaki rozegrał się w V wieku przed Chrystusem w starożytnej Grecji. Dyskursywny i dialektyczny charakter tej refleksji odbija się również w dialogach platońskich, a wątek rozmowy czy sporu towarzyszył filozofii od tego czasu nieustannie. Także filozofia dwudziestego wieku odnotowała szereg spektakularnych i ważnych debat, jak choćby ta z 1929 roku z udziałem Ernsta Cassirera i Martina Heideggera na konferencji w Davos czy sytuujący się ściśle w obrębie filozofii polityki spór Leo Straussa z Aleksandre Kojève'em w latach 1949-1951.

Może zatem budzić pewne zdziwienie, iż wspomniany przed chwilą Strauss oraz inna wielka postać filozofii polityki minionego wieku - Eric Voegelin - tak mało czasu poświęcili na wspólne przedyskutowanie swoich koncepcji. Jest to okoliczność dosyć szczególna, jeśli zważy się na fakt, iż dorobek tych postaci łączy wiele: antyczne inspiracje, nawiązania do klasycznej episteme politiké czy radykalna krytyka nowożytności z tych pozycji. Jednak podobieństwa te stają się dyskusyjne, jeśli zejdziemy z poziomu porównań ogólnego charakteru dorobku i zgłębimy szczegółowe aspekty myśli. 
Strauss i Voegelin przez wiele lat utrzymywali ze sobą kontakt korespondencyjny ${ }^{1}$, co miało miejsce - należy to podkreślić - w okresie ich największego rozwoju intelektualnego. Szczególnie intensywna korespondencja przypada na lata $1942-1953^{2}$, kiedy obserwujemy liczne wymiany zdań na temat niektórych własnych tekstów ${ }^{3}$,jak i innych zagadnieńn ${ }^{4}$.

Właściwie jedynym tego typu obszernym zapisem bezpośredniej konfrontacji jest prezentowana powyżej dyskusja, dla której punktem wyjścia była książka Straussa On Tyranny. An Interpretation on Xenophon's "Hiero"s. Wydaną w roku 1948 pracę Straussa Eric Voegelin zrecenzował w cenionym czasopiśmie naukowym - „The Review of Politics”, natomiast Strauss odpowiedział Voegelinowi na ten tekst $\mathrm{w}$ obszernym eseju Restatement on Xe-

Korespondencja między Straussem a Voegelinem została wydana po śmierci obu autorów jako: Faith and Political Philosophy. The Correspondence between Leo Strauss and Eric Voegelin 1934-1964, red. P. Emberley, B. Cooper, Columbia-London 2004 (1993). Choć w tytule tego tomu widnieje cezura czasowa, która sugeruje aż trzydziestoletni okres wymiany korespondencji i faktycznie pierwszy list (Voegelina do Straussa) jest z 1934 roku, jednak drugi pochodzi dopiero z roku 1942 i faktycznie wtedy rozpoczyna się regularna wymiana listów. De facto koniec zaś ma miejsce w 1953 roku i choć do 1964 nadal wymieniają miedzy sobą listy, to jednak (między 1953 a 1964 rokiem) ograniczają się do grzecznościowych i nie nazbyt częstej wymiany zdań.

$2 \quad$ Na te lata przypada 45 z 52 listów, jakie znajdujemy w wyżej cytowanym tomie.

3 Obszerniej (jednak w różnym stopniu) dyskutowane są teksty Voegelina (The Theory of Legal Science: A Rewiew; fragmenty History of Political Ideas - The People of God; The Origins of Scientism; The Formation of the Marxian Revolutionary Idea; The Philosophy of Existence: Plato's Gorgias, The Oxford Political Philosophers) oraz Straussa (The Intention of Rousseau; The Literary Character of The Guide for the Perplexed; Political Philosophy and History; How to Study Spinoza's Theologico-Political Treatise; Natural Right and History; On Tyranny; Walker's Machiavelli; Locke's Doctrine of Natural Right)

$4 \quad$ W korespondencji pojawia się m.in. temat Karla Poppera, głośnego wówczas za sprawą książki Społeczeństwo otwarte i jego wrogowie, w której przedstawił swoistą interpretację tradycji filozoficznej, w tym Platona. Voegelin pisze o niej: „książka jest bezczelną, dyletancką bzdurą. Każde pojedyncze stwierdzenie to skandal” (Faith and Political..., s. 67); „Książka Poppera jest skandalem bez żadnych okoliczności łagodzących; w tej intelektualnej pozie zawiera się typowy produkt upadłego umysłu; duchowo można użyć wyrażeń jak łajdacki, impertynencki, prostacki; w pojęciach technicznie fachowych, [rozpatrując - przyp. MJC] jako część historii myśli, jest dyletancki i w rezultacie bezwartościowy" (Tamże, s. 68-69). Podobnie Voegelin bardzo krytycznie wypowiada się o Locke'u („Dla mnie jest on [Locke przyp. MJC] jednym z najbardziej odrażających, haniebnych, moralnie skorumpowanych objawień w historii ludzkości”; Tamże, s. 96) Znamienne, że Strauss stroni od tak wyraźnych ocen w korespondencji z Voegelinem, natomiast na o wiele więcej pozwala sobie w listach do Kojève'a.

5 L. Strauss, On Tyranny. An Interpretation on Xenophon's 'Hiero', New York 1948.

6 "The Review of Politics", 11, 1949, s. 241-244. Recenzja jest dostępna również w: The Collected Works of Eric Voegelin, t. XXX, Selected Correspondence 1950-1984, przel. z niem. S. Adler, T. A. Hollweck, W. Petropulos, Columbia-London 2007, s. 168-174; oraz w: Faith and Political Philosophy. The Correspondence between..., s. 44-49. 
nophon's "Hiero", zawierającym także polemikę z francusko-rosyjskim heglistą Aleksandre Kojève'em (ros. Kożewnikov) ${ }^{8}$, który również krytycznie odniósł się do pracy Straussa. Stąd, pomimo bezsprzecznego pokrewieństwa intelektualnego, do którego przyznawali się zarówno Strauss, jak i Voegelin, co ma też odzwierciedlenie $\mathrm{w}$ częstym porównywaniu obu postaci przez badaczy ${ }^{9}$, dyskusja o pracy Straussa pozostaje jedyną publiczną, sformułowaną wprost polemiką między tymi autorami.

\section{Kontekst polemiki}

Badającym myśl zarówno Straussa jak Voegelina, interesujący wydać się może szczególny moment w biografiach obu autorów, kiedy doszło do tej polemiki. Przede wszystkim warto zaznaczyć, iż za sprawą okoliczności natury politycznej (dojście Hitlera do władzy, Anschluss Republiki Austrii, wybuch drugiej wojny światowej) zmuszających do opuszczenia Starego Kontynentu, obaj autorzy osiadają na dobre w Stanach Zjednoczonych, stając się obywatelami tego $\mathrm{kraju}^{10} \mathrm{i}$ na dobre wchodząc $\mathrm{w}$ środowisko intelektualne i uniwersyteckie, jednak zachowując przy tym stosunek zdystansowany względem głównego nurtu nauki o polityce. Strauss od 1938 roku wykładał na New School for Social Research - placówce zdominowanej przez pochodzących z Europy badaczy o lewicowej proweniencji. Tuż po wydaniu On Tyranny przeniósł się na Uniwersytet w Chicago, gdzie w ciągu dwóch kolejnych dekad zyskał pozycję wybitnego znawcy klasycznej filozofii oraz twórcy kontrowersyjnej szkoły. Z kolei Voegelin po przybyciu latem 1938 roku do Stanów Zjednoczonych i po kilku latach szukania stałego miejsca pracy, osiadł w 1942 roku na Uniwersytecie Stanowym Louisiany w Baton Rouge, gdzie pozostał aż do końca lat pięćdziesiątych.

Podobieństwa zachodzą także na gruncie ich biografii intelektualnej. Druga połowa lat czterdziestych to nie tylko próba zadomowienia się w nowym kraju, lecz również czas, kiedy autorzy Ci po wielu latach milczenia de-

Pierwotnie ten esej ukazał się we francuskim wydaniu On Tyranny w 1954 roku (L. Strauss, De la Tyranie, Paris 1954), po czym w 1959 roku w języku angielskim (L. Strauss, Restatement on Xenophon's Hiero, w: Tenże, What is Political Philosophy? And Other Studies, Glencoe, Illinois 1959, s. 95-113). W 2000 roku ukazała się rozszerzona (o esej Kojève’a, odpowiedź Straussa na zarzuty Voegelina i Kojève'a oraz korespondencję między Straussem a Kojève'em) wersja On Tyranny (L. Strauss, On Tyranny, V. Gourevitsch, M. S. Roth (red.), Chicago 2000).

8 Jak podaje badacz Straussa, Ryszard Mordarski, recenzje Voegelina i Kojève’a były jedynymi znaczącymi reakcjami na książkę Straussa. Zob. R. Mordarski, Klasyczny racjonalizm polityczny w ujęciu Leo Straussa, Bydgoszcz 2007, s. 195.

$9 \quad$ Zob. T. V. McAlister, Revolt Against Modernity. Leo Strauss, Eric Voegelin and Search for a Postliberal Order, Kansas 1995; B. Cooper, Eric Voegelin and the Foundations of Modern Political Science, Columbia-London 1999, s. 120-160.

10 Zarówno Strauss jak i Voegelin otrzymali obywatelstwo amerykańskie w 1944 roku. 
biutują książką w Ameryce. W przypadku Straussa tą pracą jest właśnie dyskutowana tu On Tyranny. Voegelin zmagający się w tamtym czasie z monumentalnym projektem historii idei politycznych, swoją pierwszą pracę w Stanach Zjednoczonych - Nowa naukę polityki - publikuje dopiero w 1952 roku. Rzut oka na dorobek obu autorów pozwala stwierdzić, że te książki miały dla każdego z nich kapitalne znaczenie. Voegelin Nowa nauka polityki przełamując, trwający od około 1944 roku, kryzys związany z badaną przez siebie kwestią statusu idei politycznych, otwiera tą pracą zupełnie nową perspektywę, która będzie charakterystyczna dla całej jego późniejszej twórczości. Podobnie jest w przypadku Straussa, choć trzeba przyznać, iż dzieło poświęcone analizie dialogu Ksenofonta, nie oznacza przełomu o tak zasadniczych konsekwencjach, jak w przypadku Voegelina. Jest to raczej czas ostatecznego wypracowania swego oryginalnego stanowiska, będący raczej płynnym rozwinięciem zainteresowań z poprzedniego okresu ${ }^{11}$. On Tyranny badacze dorobku Straussa uznają za niezwykle ważną w tym względzie, iż to tutaj po raz pierwszy pojawiają się wszystkie charakterystyczne cechy dla tego, co określa się mianem szkoły Straussa (straussizmu): spór starożytnych z nowożytnymi, przeciwstawienie aktywności filozoficznej i politycznej, kwestia pisarstwa ezoterycznego i egzoterycznego, problem teologicznopolityczny ${ }^{12}$. Jest to więc dla Straussa i Voegelina okres niezwykle intensywnej pracy. Dobrze ukazuje to zresztą wspomniana tu wcześniej korespondencja.

Z punktu badacza myśli obu autorów nie bez znaczenia pozostaje też fakt, iż jest to jedyny moment $w$ ich biografiach, kiedy dochodzi do tak bliskich kontaktów. Nigdy przed tym ani nigdy po tym okresie nie dochodziło między nimi do otwartej wymiany argumentów. Dyskusja na temat On Tyranny rozrywa się w samym środku dekady (1942-1953), kiedy ich kontakty są najbardziej ożywione.

Warto również zaznaczyć, iż, biorąc pod uwagę sam przedmiot badań, również mamy do czynienia z okresem szczególnym. Lata tuż po zakończeniu drugiej wojny światowej to czas, kiedy problem tyranii jest jak najbardziej aktualny. Choć upada tyrania nazistowska, u szczytu potęgi pozostaje

11 Badacze wyróżniają trzy okresy w twórczości Straussa: (1) Trwający do 1938 roku tzw. „prestraussiański”, w którym Strauss zgłębia przede wszystkim problem teologicznopolityczny w pracach o Spinozie, Hobbesie, Majmonidesie i średniowiecznej filozofii arabskiej; (2) Trwający od 1938 do 1954 roku, kiedy uwaga badacza koncentruje się na zagadnieniu prawa naturalnego i problemie tyranii; (3) Trwa od 1954 do śmierci w 1973, kiedy Strauss skupia się niemal wyłącznie na badaniach klasycznej filozofii greckiej. Zob. R. Mordarski, dz. cyt., s. 12-14.

12 R. Mordarski, Klasyczny racjonalizm polityczny..., s. 186. Zob. V. Gourevitch, Philosophy and Politics, cz. I, „The Review of Metaphisics”, T. 32, nr 2, s. 58-59. 
reżim stalinowski, natomiast inne - jak tyrania maoistowska w Chinach rodzą się niemalże „na oczach” dyskutujących badaczy. Stąd prezentowana poniżej dyskusja Straussa z Voegelinem, choć porusza zagadnienia na płaszczyźnie filozofii polityki i unika odwoływania się do bieżących wydarzeń, bez wątpienia pośrednio odnosi się także do tych zjawisk.

W o wiele sławniejszej debacie Straussa z Kojève'em ${ }^{13}$ dotyczącej również tej książki, spór przebiega wyraźnie na płaszczyźnie innego rodzaju. W tym przypadku - jak pisze Ryszard Mordarski - „ścierają się w niej dwa skrajne stanowiska: antyczna cnota i kontemplacyjna postawa klasycznego mędrca, prezentowana przez Straussa, przeciwstawiona jest nowoczesnej wiedzy i rewolucyjnej propagandzie, wyznawanej przez Kojève'a (...) Toteż w tym sporze mamy do czynienia z praktyczną prezentacją konfliktu, nazywanego przez Straussa sporem pomiędzy starożytnymi i nowożytnymi" ${ }^{14}$.

Zawieszając w tym miejscu werdykt, czy faktycznie takie ujęcie tej kwestii jest uprawnione ${ }^{15}$, można stwierdzić, iż sława, jaką zdobyła debata Straussa z Kojève'em, miała zapewne swe przyczyny również w tym, iż wyrażała spektakularny pojedynek dwóch niezwykle przenikliwych umysłów pochodzących z różnych tradycji intelektualnych. W tym świetle dyskusja Straussa $\mathrm{z}$ Voegelinem wygląda na mało efektowny i drobiazgowy spór w obozie rzeczników starożytnej episteme, dyskusję o ściśle akademickim charakterze, gdzie autorzy spierają się o kwestie drugorzędne.

\section{Znaczenie filozoficzne}

Czy jednak faktycznie konfrontacja Voegelina z Straussem powinna być tak odczytywana? Przed rozważaniem tego pytania przypomnijmy pokrótce, co jest faktycznie przedmiotem sporu. Voegelin zwraca w swej re-

13 Odbicie tego znajdujemy także w polskiej literaturze, gdzie dostępne jest kilka obszernych omówień i interpretacji tej kwestii: Patrz: S. Rosen, Hermeneutyka jako polityka, przeł. P. Maciejko, Warszawa 1998, s. 119-183; M. Kwiek, Dylematy tożsamości. Wokót wizerunku filozofa w powojennej myśli francuskiej, Poznań 1999, s. 44-56; P. Nowak, Ontologia sukcesu. Esej przy filozofii Aleksandre’a Kojève'a, Gdańsk 2006, s. 92-141; R. Mordarski, dz. cyt., s. 195-212. Zupełny brak natomiast odniesień do debaty Straussa z Voegelinem. Nie zwraca na nią uwagę nawet R. Mordarski w książce poświęconej w całości Straussowi.

14 R. Mordarski, dz. cyt., s. 196. Shadia Drury nazywa ten spór konfrontacją podejścia klasycznego i stalinowskiego - w jej ocenie: dwóch najbardziej charakterystycznych obecnie postaw intelektualnych. Zob. S. B. Drury, Debate with Leo Strauss, w: Aleksandre Kojève. The Roots of Postmodern Politics, New York 1994, s. 157-159.

15 Odmiennie na spór Straussa z Kojève'em patrzy Marek Kwiek. Według niego „obaj autorzy prezentują tutaj taką samą koncepcję filozofa, jako tego, kto ma za zadanie kształtowanie biegu historii poprzez doradzanie tyranom, kształtowanie obrazu świata na miare swoich filozoficznych koncepcji, przykrawanie go na miarę własnych przesądzeń filozoficznych" (M. Kwiek, dz. cyt., s. 45). 
cenzji uwagę na następujące aspekty analizy Straussa. Naprzód zarzuca Straussowi nieuwzględnienie historycznego wymiaru dzieła Ksenofonta, czyli - jak mówi - „sytuacji postkonstytucyjnej”, w której kategoria tyranii jest, jego zdaniem, nieadekwatna i „traci na znaczeniu, jakie ma w sytuacji, kiedy rządy prawa są realną alternatywą". Twierdzi przy tym, iż Ksenofont posługuje się pojęciem tyranii jedynie warunkowo, z racji braku właściwszego terminu odpowiedniego dla „sytuacji postkonstytucyjnej”. Voegelin sugeruje, że bardziej poprawne w sytuacji postkonstytucyjnej jest posługiwanie się pojęciem Cezara (cezaryzmu) jako „mściciela zdeprawowanych”, postaci, która stara się okiełznać stan nieładu. Takie postawienie problemu przez Voegelina ujawnia pewien odmienny charakter jego myśli względem podejścia Straussa. Różnice dotyczą przede wszystkim wrażliwości historycznej ujęcia Voegelina, rozpatrującego rozmaite problemy teoretyczne (tak jak tu problem tyranii) w pewnym osoczu historycznym, w konkretnej sytuacji egzystencjalnej, zawsze rodzącej swoiste wyzwania dla badacza. W tym punkcie dociekania Straussa mają charakter statyczny i ahistoryczny.

Rozważając kwestię podobieństwa i różnic refleksji Straussa i Voegelina, warto też wspomnieć, iż takie rozpatrywanie problemu tyranii nasuwa skojarzenia z myślą Carla Schmitta i można nawet powiedzieć o pewnym pokrewieństwie z autorem 0 pojęciu polityczności ${ }^{16}$. Podobnie jak Schmitt, Voegelin rozpatruje problem jako konkretnie "tu oto" istniejące warunki i okoliczności. Tym samym kładzie nacisk na sytuację „postkonstytucyjną" jako wyjątkową i specyficzną, jako stan wyjątkowy, kiedy zawieszone jest normalne myślenie o polityce, w którym pojęcie tyranii (jako zdeprawowanej formy królestwa) traci na znaczeniu. Choć Schmitt mówi nie o cezarze, lecz dyktatorze, perspektywa nasuwa pewne podobieństwa warte wnikliwszego rozpatrzenia w innym miejscu.

Takie ujęcie Voegelina spotyka się z zarzutami Straussa, który poddał także gruntownej i niezwykle przenikliwej krytyce myśl Schmitta ${ }^{17}$, zarzucając mu - jak pisze obrazowo Piotr Graczyk - iż „Schmitt głęboko wbija łopa-

16 W dorobku Voegelina jest niezwykle mało odwołań do Schmitta. Jedyne istotne wypowiedzi Voegelina to pochodząca z 1931 roku recenzja (choć trzeba przyznać, że obszerna) książki Schmitta Verfassungslehre. Zob. E. Voegelin Die Verfassungslehre von Carl Schmitt, w: The Collected Worsk of Eric Voegelin, t. XIII, Selected Book Reviews, przeł. z niem. J. Cockerill, B. Cooper, Columbia-London 2001, s. 42-66 oraz fragment pracy Der Autoritare Staat z 1933 (Tenże, The Authoritarian State: An Essay on the Problem of the Austrian State, przeł. z niem. R. Hein, University of Missouri Press, Columbia-London 1999, s. 58-63).

17 L. Strauss, Uwagi do pojęcia polityczności Carla Schmitta, przeł. P. Graczyk, B. Kuźniarz, „Kronos”, nr 2, 2008, s. 58-73.0 dużej wartości tego, pochodzącego z 1932 roku tekstu może świadczyć fakt, iż Schmitt bardzo wysoko cenił analizę Straussa, pomagając jej autorowi uzyskać stypendium Rockefellera i wyjazd z nazistowskich Niemiec. 
tę w europejski grunt teoretyczny, ale nie dokopuje się do Platona, a jedynie do Hobbesa"18. Mówiąc inaczej, Schmitt wedle Straussa nie przekracza ram nowożytności - prawdziwego Rubikonu w rozprawianiu o współczesnych problemach. Ciężko powiedzieć to o postawie Voegelina, co nie wyklucza jednak, iż jego myśl może posiadać również pewne wyraźne rysy sugerujące nieklasyczne wpływy.

Jeżeli faktycznie zachodzi takiego rodzaju pokrewieństwo między Schmittem a Voegelinem, które wykracza poza kwestię teologii politycznej, pozwala to znacznie zniuansować recepcję myśli samego Voegelin, już nie tylko jako ortodoksyjnego rzecznika klasycznego stanowiska, lecz także jako autora będącego pod dużym wpływem tendencji nowożytnych. Znamienne, że w wydanej kilka lat po polemice Nowej nauce polityki, choć otrzymujemy bardzo jasny obraz nowożytności jako gnostyckiej degeneracji, znajdujemy również liczne słowa uznania pod adresem Hobbesa ${ }^{19}$. Dodać tu należy, że Voegelin był uczniem Ohtmara Spanna, myśliciela konserwatywnego pozostającego pod wpływem niemieckiego idealizmu, oraz że w późniejszych latach jednym $z$ centralnych tematów myśli Voegelina była charakterystyczna dla niemieckiego idealizmu przełomu XVIII i XX wieku teoria świadomości ${ }^{20}$, a jednym z ważniejszych inspiratorów - wybitny przedstawiciel tego nurtu: Friedrich Wilhelm Joseph von Schelling ${ }^{21}$. Oczywiście z samego faktu, że myśl Voegelina nie pokrywa się we wszystkich zasadniczych punktach z wykładnią Straussa, nie powinno się automatycznie wywodzić, iż autor Order and History to nowożytnik. Byłoby to nazbyt pochopne i zbyt daleko idące. Myśl Straussa nie jest oczywiście czymś w rodzaju papierka lakmusowego, absolutnym punktem odniesienia w rozstrzyganiu czy inny autor mieści się w klasycznych ramach, czy też nie. Jednak Voegelin nie tylko różni się od Straussa, lecz także - co wydaje się intrygujące - zajmuje stanowisko skłaniające do tego, by porównać je z filozofią polityczną Carla Schmitta, którego trudno uznać za przedstawiciela klasycznej episteme. Podobnie jak u Voegelina (czego absolutnie brakuje filozofii politycznej Straussa ${ }^{22}$ ), myśl Schmitta

18 P. Graczyk, Komentarz do uwagi Schmitta o Straussie, Tamże, s. 75.

19 „Problem ładu politycznego domagał się teoretycznego uporzadkowania i zadania tego podjął się myśliciel, który stanął na wysokości zadania, Thomas Hobbes (...) Hobbesowska teoria reprezentacji dociera wprost do istoty rzeczy". (E. Voegelin, Nowa nauka polityki, przeł. P. Śpiewak, Warszawa 1992, s. 140)

20 Nad tym problemem intensywnie pracował od około 1943 roku. Zob. E. Voegelin, Anamnesis, Notre Dame-London 1978, s. 3-35.

21 Na ten temat zobacz: J. Day, Voegelin's Published Remarks on Schelling: Variations and Thems, „Voegelin's Research News”, T. VI, nr 1, February 2003. Tenże, Voegelin, Schelling, and the Philosophy of Historical Existence, Columbia-London 2003.

$22 \mathrm{Na}$ temat porównania filozofii politycznej Straussa i Voegelina Patrz: J. M. Rhodes, Philosophy, Revelation and Political Theory: Leo Strauss and Eric Voegelin, „The Journal of 
jest czuła na transcendentny kontekst, jest refleksją określoną przez chrześcijaństwo. Od tych wpływów stroni natomiast Strauss, czyniąc to jednym z ważniejszych rysów swej filozofii politycznej. Wszystko to pozwala na postawienie hipotezy, iż umieszczanie Voegelina tylko w kontekście klasycznej greckiej filozofii polityki, jest zbyt symplicystyczne. Omawiana tu polemika ze Straussem pozwala więc na postawienie hipotezy postulującej nieklasyczny aspekt stanowiska Voegelina.

Wbrew intencji Straussa, by przywrócić Ksenofonta do grona największych myślicieli politycznych starożytności, Voegelin dowodzi także, iż dokonania autora Cyropedii nie mają większego znaczenia w rozważanym problemie tyrani w sytuacji nieładu. Tym, kto - jego zdaniem - w większym stopniu zasługuje na uwagę jest Machiavelli, jako że Strauss w swej książce często odnosi Hierona do Machiavellego, przydając tym myślicielom istotne znaczenie $^{23}$. Także Voegelin przenosi ciężar swojej refleksji na interpretację autora Księcia i wydaje się, że jest to część sporu ze Straussem o największym znaczeniu.

Voegelin, patrząc na cały jego dorobek, napisał o Machiavellim stosunkowo niewiele ${ }^{24}-\mathrm{w}$ przeciwieństwie do swego adwersarza, który komentował pisma florentczyka wielokrotnie - jednak w 1958 roku opublikował książkę poświęconą wyłącznie Machiavellemu ${ }^{25}$. Bez wątpienia jednak dla obydwu autorów jest to myśliciel bardzo ważny w kształtowaniu się nowożytności ${ }^{26}$. Dyskusja o dziele autora Księcia pozwala Voegelinowi na sformułowanie pewnej wskazówki interpretacyjnej dotyczącej tyranii współczesnych. Jego zdaniem nowożytną odmianę tyranii można zrozumieć jedynie w kontekście tradycji zachodniochrześcijańskiej, a nie helleńsko-pogańskiej. Traktuje zatem tyranie współczesne jako zjawiska o zupełnie odrębnym charakterze względem ich odmian klasycznych; twierdzi, że ten problem w postaci, z jaką zmagamy się obecnie, nie miał wcześniej miejsca. Sugeruje zatem, iż starania Straussa, by uczynić zrozumiałą współczesną tyranię po

Politics", T. 49, nr 4, 1987, s. 1036-1060; D. Germino, Leo Strauss versus Eric Voegelin on Faith and Political Philosophy, „The Political Science Reviewer”, T. 24, nr 1, 1995, s. 251-275.

23 Jak pisze Strauss w wprowadzeniu: „Zestawiając nauki Księcia z tymi, które zostały przekazane przez Hierona, można najjaśniej pojąć najsubtelniejszą i faktycznie decydującą różnicę pomiędzy nauką o polityce Sokratesa i Machiavellego" (L. Strauss, On Tyranny..., s. 24).

24 E. Voegelin, Machiavelli's Prince: Background and Formation, „Review of Politics”, nr 13, 1951, s. 142-168; Tekst ten ukazał się również w zmodyfikowanej formie: The Collected Works of Eric Voegelin, T. XXII, History of Political Ideas, T. IV, Renaissance and Reformation, D. L. Morse, W.M. Thompson (red.), pt. 4, rozdz. 1, §§ 1-5, Columbia-London 1998.

25 L. Strauss, Thoughts on Machiavelli, Glencoe 1958.

26 G.S. Schram, Strauss and Voegelin on Machiavelli and Modernity, „Modern Age”, nr 2-3, 1987, s. 261-265. 
uprzednim dogłębnym przemyśleniu klasycznych refleksji na ten temat, są źle ukierunkowane.

Voegelin przede wszystkim zaznacza, że dzieła Machiavellego nie należy interpretować - jak sugeruje to Strauss - w świetle wpływów klasycznych, w tym związków z Ksenofontem. Zasadniczymi jego źródłami jest tradycja biblijna i chrześcijańska oraz - co jest bodaj najbardziej oryginalnym i zarazem najbardziej dyskusyjnym wkładem do zrozumienia dzieła Machiavellego - postać Tamerlana (Timura), czternastowiecznego władcy azjatyckiego ${ }^{27}$. Odrzuca też interpretację dzieła florentczyka jako przejawu awerroizmu $^{28}$, wpisując je raczej w tradycję gnostycką. Należy więc uznać, iż to interpretacja Machiavellego jako autora, na którego wpłynęło przede wszystkim chrześcijaństwo, jest rozumieniem faktycznie idącym „pod prąd” zwyczajowego pojmowania dorobku autora Księcia. Współgra też z ogólną wizją wyłaniania się nowożytności, jaką Voegelin zawarł w wydanej kilka lat później Nowej nauce polityki czy w innych publikowanych w tym czasie pismach $^{29}$. Zatem nie z tradycji pogańskiej - twierdzi Voegelin - a z odradzającej się od XII wieku tradycji gnostyckiej pochodzi impuls do powstania zarówno nowego księcia, jak i rozwoju wielkich ruchów umysłowych i społecznych jak socjalizm, pozytywizm czy wreszcie radykalnie aktywistycznej odmiany współczesnego gnostycyzmu osiągającej zwieńczenie w narodowym socjalizmie czy komunizmie. W tym też kontekście należy rozumieć nowożytne tyranie.

Zmierzając do końca, warto zatrzymać się na chwilę przy samych uwagach Straussa. Wspomnieliśmy na początku tych rozważań, iż On Tyranny jest szczególną pracą w dorobku Straussa, gdyż zawiera wszystkie najistotniejsze wątki jego pisarstwa. Potwierdza to również prezentowana tu polemika, gdzie widzimy, że Strauss krytykuje historycyzm Voegelina; posługuje się krytyką metody hermeneutycznej zastosowanej przez swego adwersarza poprzez wyrażenie przekonania, iż prymarnym (i ostatecznym) zadaniem jest rozumieć autora tak, jak on sam siebie rozumiał; zaleca ezoteryzm i pod-

27 Np. Isaiah Berlin pisze, że hipoteza, iż Machiavelli silnie inspirował się postacią Tamerlana, jest „dosyć naciagana”, jednak pozostawia ta uwage bez żadnego wyjaśnienia. Zob. I. Berlin, Oryginalność Machiavellego, w: Tenże, Pod prąd, przeł. T. Bieroń, Poznań 2002, s. 96157. Więcej na ten temat u Voegelina: E. Voegelin, Machiavelli's Prince... oraz w tekście Das Timurbild der Humanisten. Eine Studie zur politischen Mythenbildung, „Zeitschrift für Recht“, nr 17, 1937, s. 545-582. Tekst dostepny w języku angielskim w tomie: Anamnesis. On the Theory of History and Politics, przeł. z niem. M. J. Hanak, University of Missouri Press, ColumbiaLondon 2002, s. 175-223.

28 Zob. E. Voegelin, Siger de Brabant, „Philosophy and Phenomenological Research”, T. 4, nr 4, 1944 , s. 507-526.

29 Np. pisany w tym czasie rozdział History of Political Ideas wydany w Polsce jako: E. Voegelin, Lud Boży, przeł. M. Umińska, Kraków 1994. 
kreśla, iż pewnego rodzaju wiedza (w tym przypadku dotycząca cezaryzmu) może być szkodliwa dla społeczeństwa ${ }^{30}$; w końcu, nie docenia czy ignoruje źródła chrześcijańskie, skupia się na autorach epoki klasycznej i nowożytnej.

\section{Uwagi końcowe}

Podsumowując, można w istocie powiedzieć - posługując się tu może nazbyt śmiałym, lecz zasadnym, porównaniem, by uwypuklić ważną kwestię odnośnie obecnej kondycji episteme politiké - że choć dla miłośnika filozofii czymś niezwykle zajmującym jest dyskusja Arystotelesa z poglądami Platona, jednak czymś zasadniczym dla zaistnienia filozofii jako takiej (w tym filozofii polityki) był spór rzeczników tej formy refleksji z sofistami czy światem mitu $^{31}$. Stąd znacznie ważniejszy w perspektywie restauracji filozofii polityki w drugiej połowie XX wieku wydaje się być nie przedstawiony tutaj spór Straussa z Voegeliem, lecz Straussa z Kojève'em. I być może, co staraliśmy się pokreślić, stanowisko Voegelina nie jest tu wolne od istotnych pierwiastków o nieklasycznym rodowodzie, jednak to poprzez polemikę Straussa $\mathrm{z}$ autorem Wstępu do wykładów o Heglu może przebiegać prawdziwa linia frontu o fundamentalnych konsekwencjach w najbardziej filozoficznym sensie tego słowa. W czasach, gdy głosi się śmierć filozofii polityki (P. Laslett), przede wszystkim spór z przeciwnikami filozofii ma kluczowe znaczenie. Tak też rozumiał chyba tę sytuację Strauss. Mówiąc słowami Carla Schmitta takie wnioski wynikają z egzystencjalnej sytuacji i taki jest prawdziwy oponent $w$ tych zmaganiach.

Jednak mając świadomość, iż w filozofii - jak nigdzie - wyznaczenie prawdziwego frontu walki oraz określenie, kto jest przyjacielem, a kto wrogiem, jest zadaniem niezwykle trudnym, niewykluczone, iż należy większe znaczenie przydać polemice Straussa z Voegelinem. Warto pamiętać, że Strauss w swej filozofii polityki wyrzeka się tradycji chrześcijańskiej. W tym więc sensie być może znajduje w Kojève’e kogoś znacznie bliższego sobie, niżby można było przypuszczać. I być może prawdziwa linia frontu biegnie w ten sposób, że to Strauss i Voegelin prezentują zupełnie odmienne obozy ${ }^{32}$.

$$
\text { M I C H A } 亡 \text { J . C Z A R N E C K I }
$$

Widać tu awerroistyczne podkreślanie dwóch prawd: publicznej i filozoficznej.

E. Voegelin, Order and History, T. 2, The Word of Polis, Baton Rouge 1957, s. 111-240.

Zob. uwagę Voegelina z recenzji Korzeni totalitaryzmu H. Arendt: „We współczesnym kryzysie prawdziwa linia podziału biegnie nie między liberałami i totalitarystami, lecz między religijnymi i filozoficznymi transcendentalistami z jednej strony a liberalnymi i totalitarnymi immanentystami z drugiej strony" (E. Voegelin, Korzenie totalitaryzmu, przeł. J. Kałążny, „Przegląd Polityczny”, nr 55, 2002, s. 141). 


\section{Abstract}

Leo Strauss and Eric Voegelin spent very little time discussing each other's ideas. This is a very telling observation, since their works share many similarities grounded in classical inspirations, references to episteme politike and radical criticism of the modernity. However, these become disputable, when instead of comparing the general character of their works, one goes deeper to the more specific aspects of their thought.

The sole direct confrontation between these two important philosophers concerns Strauss' book titled On Tyranny. An Interpretation on Xenophon's "Hiero". This work, published in 1948 by Strauss, was reviewed by Eric Vogelin in a highly regarded journal "The Review of Politics". Strauss replied to Voegelin's text in an extensive essay Restatement on Xenophon's "Hiero", which also contained the polemics with French-Russian heglist Aleksandre Kojève, who also criticized Strauss' work.

This essay is a commentary on Eric Voegelin and Leo Strauss' polemics. First, the author focuses on the context of this argument, particularly on the extraordinary stage in the biographies of both writers. Next, philosophic context of discussion is revealed; the author points out the characteristic themes of Strauss' writing appearing in the argumentation, namely affirmation of ancient writing, criticism of historicism, emphasis on esotericism and hermeneutic rules. On the other hand, it is suggested that this polemics is a proof of nonclassical inspirations of Voegelin, who could be rather compared to C. Schmitt. Lastly, the author tries to decide whether the Strauss-Voegelin argument is more or less significant than the Strauss-Kojeve debate. 